Jerrold Lerman MD FRCPC

Anthony A. Kiskis MD FRCSC

\title{
Lidocaine attenuates the intraocular pressure response to rapid intubation in children
}

To determine the effect of intravenous lidocaine on the intraocular pressure (IOP) response to laryngoscopy and intubation, twenty unpremedicated children, ages one to ten years were studied. After administration of either intravenous sterile water (control) $(n=10)$ or preservative-free lidocaine $\left(1.5 \mathrm{mg} \cdot \mathrm{kg}^{-1}\right)(n=10)$, anaesthesia was induced with pancuronium $\left(0.15 \mathrm{mg} \cdot \mathrm{kg}^{-1}\right)$, thiopentone $\left(5 \mathrm{mg} \cdot \mathrm{kg}^{-1}\right)$, and atropine $\left(0.02 \mathrm{mg} \cdot \mathrm{kg}^{-1}\right)$, and maintained with halothane, nitrous oxide and oxygen. The trachea was intubated one minute after administration of thiopentone. IOP (measured by applanation tonometry), heart rate, and systolic blood pressure were measured at the time of loss of the eyelid reflex (time 0 ), immediately after endotracheal intubation, and each minute thereafter for five minutes. In the control group, $1 O P$ increased (27 per cent) significantly after intubation $(p<0.05)$, whereas in the lidocaine group, IOP did not increase ( 9.8 per cent) significantly after intubation. IOP

\section{Key words}

ANAESTHESIA: paediatric; NEUROMUSCULAR RELAXANTS: pancuronium; EYE: intraocular presSURE; INTUBATION, ENDOTRACHEAL: rapid; ANAESTHETICS, LOCAL: lidocaine.

From the Departments of Anaesthesia and Ophthalmology, The Hospital for Sick Children, Toronto, Ontario. Presented, in part, at the annual meeting of the International Anesthesia Research Society, Houston Texas, March 1985.

Address correspondence to: Dr. Jerrold Lerman, Department of Anaesthesia, The Hospital for Sick Children, 555 University Avenue, Toronto, Ontario M5G 1 X8. decreased below time 0 values within three minutes after loss of the eyelid reflex in the lidocaine group $(p<0.05)$. At each measurement (except time 0), IOP was signifcantly greater in the control group than in the lidocaine group $(p<0.05)$. Heart rate and systolic blood pressure did not increase significantly in either group after intubation. We conclude that intravenous lidocaine $\left(1.5 \mathrm{mg} \cdot \mathrm{kg}^{-1}\right)$ significantly attenuates the IOP response to laryngoscopy and intubation in children anaesthetized with pancuronium, thiopentone, and atropine.

The drug regimen: thiopentone, atropine, and pancuronium is currently recommended for induction of anaesthesia in children with full stomachs in whom an increase in intraocular pressure is undesirable. ${ }^{1,2}$ Pancuronium is the muscle relaxant of choice in these children because its onset of action is more rapid than either d-tubocurare or gallamine ${ }^{3-5}$ and, in contrast to succinylcholine ${ }^{5-9}$ it does not increase intraocular pressure when used in doses up to $0.15 \mathrm{mg} \cdot \mathrm{kg}^{-1}$. $^{3,5,10-14}$ Although pancuronium itself does not increase intraocular pressure, laryngoscopy and tracheal intubation during light anaesthesia with thiopentone and pancuronium may increase intraocular pressure to the same extent as thiopentone and succinylcholine. ${ }^{9,14}$ To attenuate the increase in intraocular pressure during laryngoscopy and tracheal intubation, the optimal drug sequence must provide both deep general anaesthesia and profound muscle relaxation during this period.

High dose pancuronium, $0.15 \mathrm{mg} \cdot \mathrm{kg}^{-1}$, facilitates rapid tracheal intubation in patients with full stomachs. It has been suggested that the speed of onset of muscle relaxation is as rapid with pancuronium $0.15 \mathrm{mg} \cdot \mathrm{kg}^{-1}$ as with succinylcholine. ${ }^{15}$ 
However, it is our impression that muscle relaxation in children develops more slowly with pancuronium $0.15 \mathrm{mg} \cdot \mathrm{kg}^{-1}$ than with succinylcholine. ${ }^{*}$ To allow sufficient time for the onset of relaxation with pancuronium, we administer pancuronium before thiopentone. Accordingly, we recommend the drug sequence of pancuronium $0.15 \mathrm{mg} \cdot \mathrm{kg}^{-1}$, followed by thiopentone and atropine at the earliest sign of weakness, in order to provide both deep general anaesthesia and profound muscle relaxation during laryngoscopy and intubation. Although we advocate this drug sequence in children with full stomachs in whom an increase in intraocular pressure is undesirable, the effectiveness of this sequence to attenuate the increase in intraocular pressure during laryngoscopy and intubation has not been established.

Intravenous lidocaine reduces the anaesthetic requirements ${ }^{16}$ and attenuates many autonomic reflex responses during general anaesthesia. Intravenous lidocaine attenuates the cough reflex during light anaesthesia, ${ }^{17}$ attenuates the increase in intracranial pressure during tracheal suctioning, ${ }^{18,19}$ and attenuates the increases in heart rate and blood pressure during laryngoscopy and endotracheal intubation. ${ }^{20}$ Because the increase in intraocular pressure during laryngoscopy and intubation is believed to be a reflex response, ${ }^{9}$ intravenous lidocaine may also attenuate this response.

To determine whether intravenous lidocaine attenuates the intraocular pressure response to laryngoscopy and tracheal intubation in children anaesthetized with pancuronium, thiopentone, and atropine, we measured intraocular pressure, heart rate, and systolic blood pressure during induction of anaesthesia, laryngoscopy, and tracheal intubation in 20 healthy children.

\section{Methods}

With approval from our human studies review committee, informed written consent was obtained from the parents of each child prior to anaesthesia.

Twenty children, ages one to ten years, ASA physical status one or two, fasting, and unpremedicated were studied. All children were scheduled for minor surgery lasting $11 / 2$ hours or longer, and requiring tracheal intubation. Children were

*Cunliffe M, Lerman J, McLeod ME, Burrows FA. unpublished data.

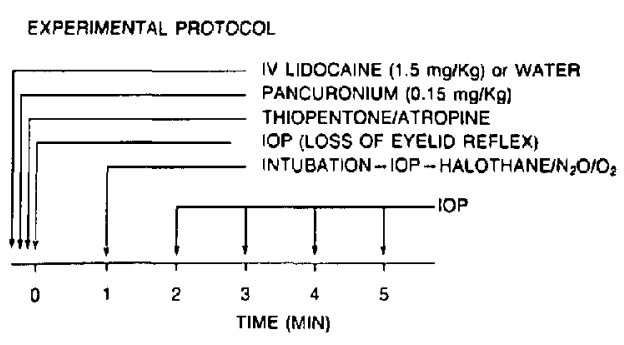

FIGURE 1 The drug sequence during induction of anaesthesia is shown on a line diagram. Time 0 measurements were recorded at the loss of the eyelid reflex. At each minute, intraocular pressure (IOP), heart rate, and systolic blood pressure were recorded.

excluded from the study if there was a history of intraocular disease, a history of neuromuscular disease, renal or hepatic insufficiency, or if a difficult intubation was anticipated.

On arrival in the operating room, each child was monitored with an electrocardiogram, precordial stethoscope, and blood pressure cuff. After a \#25 gauge butterfly needle was inserted into the dorsum of the hand, either sterile water $(2 \mathrm{ml})$ (control) $(\mathrm{n}=10)$ or preservative-free lidocaine (1.5 $\left.\mathrm{mg} \cdot \mathrm{kg}^{-1}\right)(\mathrm{n}=10)$ was administered (Figure 1$)$. The "deadspace" in the butterfly needle was flushed with $2 \mathrm{ml}$ of sterile water after each drug was administered. Each child was instructed to hold an arm straight up in the air. Pancuronium (0.15 $\mathrm{mg} \cdot \mathrm{kg}^{-1}$ ) was then administered intravenously. When the earliest sign of muscle weakness appeared (waivering or loss of coordination in the hand, wrist, or arm of the extended extremity), a mixture of thiopentone $\left(5 \mathrm{mg} \cdot \mathrm{kg}^{-1}\right)$ and atropine $\left(0.02 \mathrm{mg} \cdot \mathrm{kg}^{-1}\right)$ was administered. For those children too young to co-operate by extending an arm, thiopentone and atropine were administered approximately 15 seconds after pancuronium. After ventilating with 100 per cent oxygen by mask for one minute, the trachea was intubated rapidly and atraumatically with a straight laryngoscope blade of appropriate length. External pressure on the eye was avoided at all times. Ventilation was controlled mechanically (peak inspiratory pressure less than $20 \mathrm{~cm} \mathrm{H}_{2} \mathrm{O}$ ) with halothane (1.0-1.5 per cent dial setting) in a nitrous oxide/oxygen (70/30) mixture to maintain normocapnia (end-tidal $\mathrm{PCO}_{2}$ between $35-40 \mathrm{mmHg}$ ) (Puritan-Bennett carbon dioxide 
TABLE

\begin{tabular}{llllll}
\hline $\begin{array}{l}\text { Patient } \\
\text { groups }\end{array}$ & $\begin{array}{l}\text { Age } \\
(\mathrm{yrs})\end{array}$ & $\begin{array}{l}\text { Weight } \\
(\mathrm{kg})\end{array}$ & $\begin{array}{l}\text { lOP* } \\
(\mathrm{mmHg})\end{array}$ & $\begin{array}{l}\text { Heart rate* } \\
(\text { bpm })\end{array}$ & $\begin{array}{l}\text { Systolic } \\
\text { blood pressure* } \\
(\mathrm{mmHg})\end{array}$ \\
\hline Lidocaine $(\mathrm{n}=10)$ & $5.0 \pm 0.7$ & $18 \pm 2$ & $15.4 \pm 1.4$ & $149 \pm 7$ & $111 \pm 4$ \\
Sterile water $(\mathrm{n}=10)$ & $5.6 \pm 1.1$ & $21 \pm 4$ & $18.2 \pm 0.85$ & $149 \pm 7$ & $115 \pm 5$ \\
\hline
\end{tabular}

Mean \pm S.E.

$\mathrm{IOP}=$ intraocular pressure.

*At loss of the eyelid reflex.

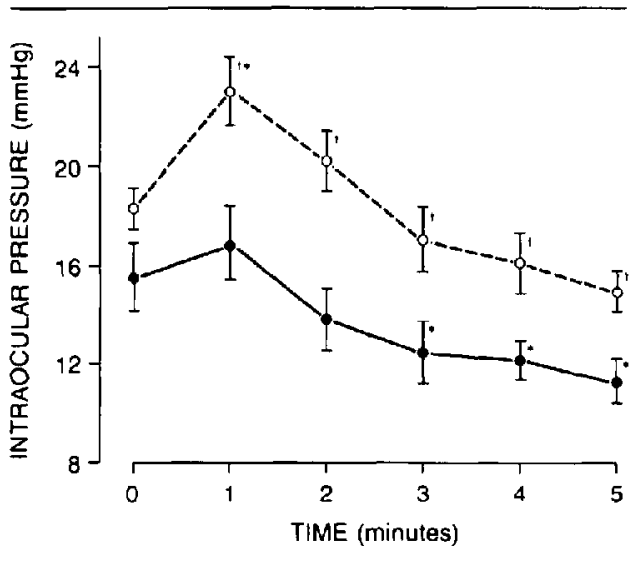

FIGURE 2 The intraocular pressure response during induction of anaesthesia in two groups of children: one group was pretreated with sterile water $(O)$ (control), while the second group was pretreated with $1.5 \mathrm{mg} \cdot \mathrm{kg}^{-1}$ intravenous lidocaine (O). In the group pretreated with sterile water, intraocular pressure increased significantly above control values after laryngoscopy and intubation (Time - $1 \mathrm{~min}$ ), whereas in the group pretreated with intravenous lidocaine, intraocular pressure did not increase significantly after laryngoscopy and intubation. Mean \pm S.E. ${ }^{*} p<0.05$ differ from control values. $\dagger_{p}<0.05$ differ between the two groups.

monitor). Positive end-expiratory pressure was avoided. Each patient was supine and horizontal throughout the study period.

Intraocular pressure, heart rate, and systolic blood pressure were measured at the time of loss of the eyelid reflex (time 0 ), immediately after intubation (within 10-20 seconds), and each minute thereafter for five minutes (Figure 1). After a drop of fluorescein solution was placed in one eye, the eyelids were separated with a paediatric lid speculum and the intraocular pressure was measured with a hand-held Perkins applanation tonometer. ${ }^{21}$ After each measurement, the fluorescein solution was irrigated from the eye with a balanced salt solution. Heart rate was recorded on a Hewlett-Packard 78342A monitor. Systolic blood pressure was measured by palpation with a Riva Rocci occlusive cuff. Intubating conditions were judged by the anaesthetist according to the criteria of Lund and Stovner. ${ }^{22}$ Surgical incision followed completion of the study.

Intraocular pressure was measured by one observer and anaesthesia administered by the second observer.

Statistical significance $(p<0.05)$ was determined using the Bonferroni $t$ test, ${ }^{23}$ two-way ANOVA, and the Student-Newman-Keuls multiple range test. ${ }^{24}$

\section{Results}

The demographic data and control values for intraocular pressure, heart rate, and systolic blood pressure did not differ significantly between the two groups (Table).

In the control group, intraocular pressure increased (27 per cent) significantly above time 0 values after intubation $(p<0.05)$ whereas, in the lidocaine group, intraocular pressure did not increase $(9.8$ per cent) significantly above time 0 values after intubation (Figure 2). In the lidocaine group, intraocular pressure decreased significantly below control values by three minutes $(\mathrm{p}<0.05)$. Intraocular pressure was significantly greater in the control group than in the lidocaine group at all times ( $p<0.05$ ), except time 0 .

Heart rate and systolic blood pressure did not increase significantly above time 0 values in either group, although systolic blood pressure did decrease significantly below control values by four and five minutes in the lidocaine group ( $p<0.05$ ) (Figures 3 and 4). Heart rate and systolic blood 


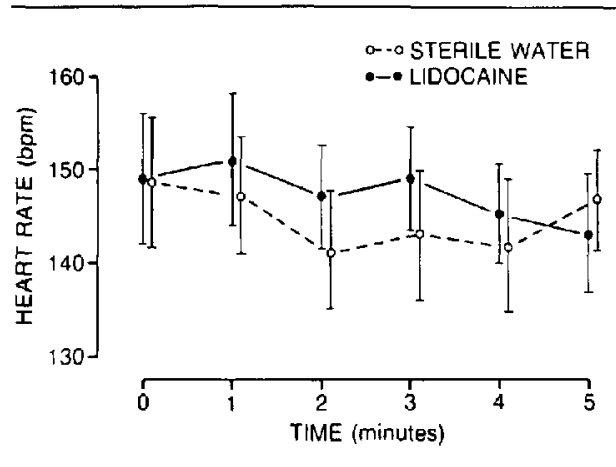

FIGURE 3 Heart rate did not change significantly after induction of anaesthesia, laryngascopy, or intubation in either group. Mean \pm S.E

pressure did not differ between the two groups at any time (Figures 3 and 4 ).

The mean ( \pm S.E.) $\mathrm{PCO}_{2}$ in the control group, $39 \pm 0.6 \mathrm{mmHg}$, did not differ significantly from the $\mathrm{PCO}_{2}$ in the lidocaine group, $36.9 \pm 0.9$ $\mathrm{mmHg}$

Intubating conditions were excellent for each child in both groups: the vocal cords were midposition and fixed, and there was no bucking, or coughing when the endotracheal tube was inserted into the trachea. There were no ophthalmological, anaesthetic or neurological complications in this study.

\section{Discussion}

Intravenous lidocaine $\left(1.5 \mathrm{mg} \cdot \mathrm{kg}^{-1}\right)$ significantly attenuates the intraocular pressure response to laryngoscopy and tracheal intubation in healthy children anaesthetized with pancuronium, thiopentone, and atropine when the lidocaine is administered approximately 75 seconds before laryngoscopy (i.e., immediately before induction of anaesthesia). The effectiveness of intravenous lidocaine in this study is consistent with previous reports in which lidocaine attenuated other reflex responses. ${ }^{16-20}$ Although lidocaine attenuates many autonomic reflex responses, it does not prevent the direct increase in intraocular pressure caused by succinylcholine. ${ }^{25,26}$ Thus, intravenous lidocaine effectively attenuates the increase in intraocular pressure which occurs during laryngoscopy and tracheal intubation in children.

It is commonly assumed that the drug sequence of pancuronium $\left(0.15 \mathrm{mg} \cdot \mathrm{kg}^{-1}\right)$ followed by thiopentone $\left(5 \mathrm{mg} \cdot \mathrm{kg}^{-1}\right)$, and atropine $\left(0.02 \mathrm{mg} \cdot \mathrm{kg}^{-1}\right)$ prevents increases in intraocular pressure because it produces both deep general anaesthesia and profound muscle relaxation during laryngoscopy and tracheal intubation. The drug sequence, pancuronium, thiopentone, and atropine does provide deep general anaesthesia during tracheal intubation because it prevents significant circulatory responses to laryngoscopy. However, this drug sequence does not prevent significant increases in intraocular pressure (27 per cent) during laryngoscopy even though normocapnia is maintained, ${ }^{27}$ and positive end-expiratory pressure ${ }^{28}$ and external ocular pressure are avoided. This differential response to laryngoscopy and intubation suggests that caution should be exercised when extrapolating the response of one variable (i.e., intraocular pressure) from the response of other variables (i.e., circulatory variables). The drug sequence pancuronium, thiopentone, and atropine does not prevent significant increases in intraocular pressure during laryngoscopy and intubation in children.

Transient increases in intraocular pressure in children with penetrating eye injuries may further damage the already injured eye. The extent of this further damage depends on the size, severity, and location of the penetrating wound, and the magnitude of the increase in intraocular pressure. Because the full extent of the existing ocular injury cannot often be determined before anaesthesia, any significant increase in intraocular pressure is undesirable. The complications of increases in intraocular pressure in children with open eye injuries include prolapse of intraocular structures such as uyeal tissue, lens, vitreous, and retina. If intraocular structures prolapse, they must often be removed surgically. This decreases prognosis for recovery of vision. Prolapse of vitreous humor into the anterior chamber of the eye may cause glaucoma, retinal detachment, and corneal decompensation. The drug sequence recommended for induction of anaesthesia in these children will minimize any significant increase in intraocular pressure and reduce the associated ocular complications.

The administration of high dose pancuronium $\left(0.15 \mathrm{mg} \cdot \mathrm{kg}^{-1}\right)$ is not without risk in some children. High dose pancuronium is absolutely contraindicated in those children in whom a difficult intubation is anticipated and relatively contraindicated in 


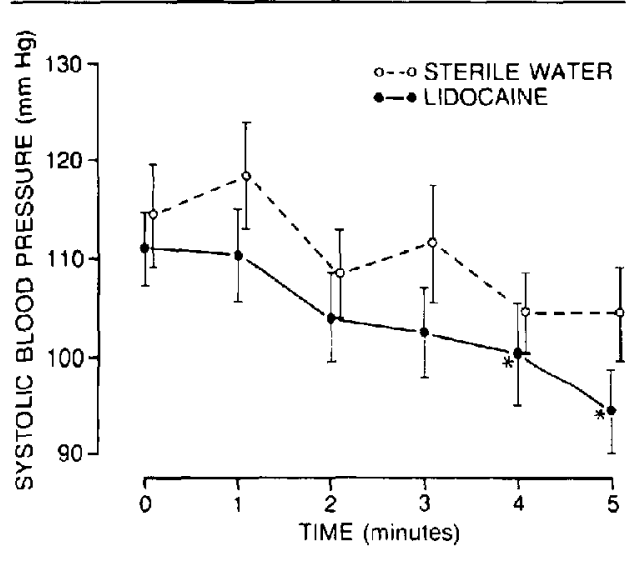

FIGURE 4 Systolic blood pressure did not increase signifcantly after induction of anaesthesia, laryngoscopy, or intubation in either group. In the group pretreated with intravenous lidocaine, systolic blood pressure decreased significantly* $(p<0.05)$ below control values at 4 and $5 \mathrm{~min}$. Mcan \pm S.E.

children in whom tachycardia and hypertension are undesirable or in children with renal failure or severe neuromuscular disease.

The induction technique described here requires a secure intravenous route. The loss of intravenous access between administration of pancuronium and thiopentone could produce awareness and possibly recall. Intravenous access could be lost if the intravenous became interstitial or if thiopentone mixed with trace amounts of residual pancuronium present in the intravenous. In the latter case, thiopentone could precipitate out of solution, and occlude the intravenous. $\dagger$ ln order to prevent this, the intravenous tubing must be flushed with a crystalloid solution between administration of the pancuronium and thiopentone. The risk of awareness with this drug regimen underscores the necessity for both a secure intravenous and a thorough flush of the intravenous after administration of each drug.

The rapid intravenous administration of 1.5 $\mathrm{mg} \cdot \mathrm{kg}^{-1}$ lidocaine may produce hypotension, arrhythmias, and seizures. ${ }^{30-32}$ Although intravenous lidocaine is not commonly associated with complications during induction of anaesthesia, intravenous lidocaine should be administered slowly (over a period of 20-30 seconds). This will reduce

† Morton Wm, Lerman J. Unpublished data. the peak venous concentration and minimize the risk of transient systemic complications. ${ }^{30,31}$

The intubating conditions for both groups of children paralyzed with pancuronium $0.15 \mathrm{mg} \cdot \mathrm{kg}^{-1}$ were excellent. When pancuronium $0.15 \mathrm{mg} \cdot \mathrm{kg}^{-1}$ is administered approximately 15 seconds before thiopentone, profound muscle relaxation appears to coincide clinically with the maximum depth of anaesthesia at 50-60 seconds after thiopentone

Intravenous lidocaine $\left(1.5 \mathrm{mg} \cdot \mathrm{kg}^{-1}\right)$ significantly attentuates the intraocular pressure response to laryngoscopy and tracheal intubation in children anaesthetized with pancuronium $\left(0.15 \mathrm{mg} \cdot \mathrm{kg}^{-1}\right)$, thiopentone (5 $\mathrm{mg} \cdot \mathrm{kg}^{-1}$ ), and atropine $(0.02$ $\mathrm{mg} \cdot \mathrm{kg}^{-1}$ ). This drug sequence is recommended for induction of anaesthesia in children with full stomachs in whom an increase in intraocular pressure is undesirable.

\section{Acknowledgement}

We thank Dr. J.D. Morin for his assistance in completing this study and manuscript.

\section{References}

1 France NK. Anesthesia for pediatric ophthalmic surgery. In: Pediatric Anesthesia, pp 794-6, edited by Gregory GA, New York: Churchill Livingston, 1983.

2 Steward $D J$. Ophthalmology for penetrating eye injuries. In: Manual of Pediatric Anesthesia, pp 135-7, 2nd Edition, New York: Churchill Livingston, 1985.

3 George $R$, Nuisingh A, Downing JW, et al. Nondepolarizing neuromuscular blockers and the eye. A study of intraocular pressure. Br J Anaesth 1979; 51: 789-92.

4 Blackburn CL. Margan $M$. Comparison of speed of onset of action of fazadinium, pancuronium, tubocurare and succinylcholine. Br J Anaesth 1978; 50: $361-4$.

5 Hey VMF. Relaxants for endotracheal intubation. A comparison of depolarizing and non-depolarizing neuromuscular blocking agents. Anaesthesia 1973; 28: 32-6.

6 Lincoff WA, Ellis CN, Devoe AG, et al. The effect of succinylcholine on intraocular pressure. Am J Ophthal 1955; 40: 501-10.

7 Schwartz $H$, DeRoetth Jr A. Effect of succinylcholine on intraocular pressure in human beings. Anesthesiology 1958; 19: 112-3. 
8 Craythorne NWB, Rottenstein MS, Dripps RD. The effect of succinylcholine on intraocular pressure in adults, infants and children during general anaesthesia. Anesthesiology 1960; $21: 59-63$.

9 Wynands JE, Crowell DE. Intraocular tension in association with succinylcholine and endotracheal intubation: a preliminary report. Can Anaesth Soc J I960; 7: 39-43

10 Smith $R B$, Leano $N$. Intraocular pressure following pancuronium. Can Anaesth Soc J 1973; 20: 742-6.

11 Litwiller RW, Difazio CA, Rushia EL. Pancuronium and intraocular pressure. Anesthesiology 1975; 42: 750-2.

12 Patenaude BL, Robblee JA, Gardner Watson, A. The value of pancuronium in prolonged intraocular operations. Can J Ophthal 1977; 12: 265-7.

13 Al-Abrak MH, Samuel JR. Effects of general anaesthesia on the intraocular pressure in man. Comparison of tubocurarine and pancuronium with nitrous oxide and oxygen. Br J Ophthal 1974; 58: 806-10.

14 Lerman J, Kiskis AA. Effects of high-dose pancuronium and light anaesthesia on intraocular pressure in children. Anesthesiology 1984; 61: \$434.

15 Brown EM, Krishnaprasad D. Smiler BG. Pancuronium for rapid induction technique for tracheal intubation. Can Anaesth Soc J 1979; 26: 489-91.

16 Himes JrRS, DiFazio CA, Burney RG. Effects of lidocaine on anesthetic requirements for $\mathrm{N}_{2} \mathrm{O}$ and halothane. Anesthesiology 1977; 47: 437-40.

17 Poulton TJ, James FM III. Cough suppression by lidocaine. Anesthesiology 1979; 50: 470-2.

18 Bedford RF, Persing $J A$, Pobereskin L, Butler A. Lidocaine or thiopental for rapid control of intracranial hypertension? Anesth Analg 1980; 59 : 435-7.

19 Bedford RF, Winn HR. Tyson $G$, et al. Lidocaine prevents increased ICP after endotracheal intubation. In intracranial pressure IV, pp. 95-8, edited by Shulman K, Marmarou A, Miller JD, et al. New York: Springer Verlag, 1980.

20 Abou-Madi MN, Keszler H, Yacoub JM. Cardiovascular reactions to laryngoscopy and tracheal intubation following small and large intravenous doses of lidocaine. Can Anaesth Soc J 1977; 24: 12-19.

21 Perkins ES. Hand-held applanation tonometer. $\mathrm{Br} \mathrm{J}$ Ophthal 1965; 49: 591-3

22 Lund I, Stovner J. Dose-response curves for tubocurarinc, alcuronium, and pancuronium. Acta Anaesthesiol Scand Suppl 1970; 37: 238-43.
23 Glantz SA. Primer of Biostatistics, pp. 87-8, New York; McGraw-Hill, 1981.

$24 \mathrm{Zar} J H$. Biostatistical analysis. pp. 15I, 163, New Jersey; Prentice-Hall Inc, 1974

25 Smith RB, Babinski $M$, Leano $N$. The effect of lidocaine on succinylcholine produced rise in intraocular pressure. Can Anaesth Soc J 1979; 26: 432-3.

26 Pandey $K$, Badola $R P$, Kunar $S$. Time course of intraocular hypertension produced by suxametho. nium. Br J Anaesth 1972; 44: 191-5.

27 Samuel JR, Beaugié $A$. Effect of carbon dioxide on the intraocular pressure in man during general anaesthesia. Br J Ophthal 1974; 58: 62-7.

28 Rosen DA, Johnston VC. Ocular pressure patterns in the valsalva manoeuver. Arch Ophthal 1959; 62: 810-816.

29 Stoelting $R K$. The hemodynamic effects of pancuronium and d-tubocurarine in anaesthetized patients. Anesthesiology 1972; 36: 612-15.

30 Roos JC, Dunning AJ. Effects of lidocaine on impulse formation and conduction defects in man. Am Heart J 1975; 89: 686-99.

31 Covino $B G$. Systemic toxicity of local anesthetic agents. Anesth Analg 1978; 57: 387-8.

32 MCWhirter WR, Schmidt FH, Frederickson EL, Steinhaus JE. Cardiovascular effects of controlled lidocaine overdosage in dogs anesthetized with nitrous oxide. Anesthesiology 1973; 39: 398-404. 
Résumé

Afin de déterminer l'effet de l'administration intraveineuse de tidocaine sur fa pression intra-oculaire (IOP) lors de la laryngoscopie et l'intubation, vingt enfants non-prémédiqués, âgés de un à dix ans ont été étudiés. Après l'administration intraveineuse soit de l' eau stérile (contrôle) $(n=10)$, ou de lidocaine sans préservatif $(1.5$ $\left.m g^{\prime} \mathrm{kg}^{-1}\right)(n=10)$, l'anesthésie a été induite avec du pancuronium $\left(0.15 \mathrm{mg} \cdot \mathrm{kg}^{-1}\right)$, thiopentone $\left(5 \mathrm{mg} \cdot \mathrm{kg}^{-1}\right.$ ), et atropine $\left(0.02 \mathrm{mg} \cdot \mathrm{kg}^{-1}\right)$. L'anesthésie a été maintenue avec l'halothane, le protoxyde d'azote et l'oxygène. La trachée a été intubée après une minute de l'administration de thiopentone. IOP (mesurée par tonométrie), la fréquence cardiaque ainsi que la tension artérielle systolique ont été mesurées lors de la perte du réflexe ciliaire (temps 0), immédiatement après intubation endotrachéale et par la suite à chaque minute pour cinq minutes. Dans le groupe contrôle, l'IOP augmenta 27 pour cent) significativement après intubation $(p<0.05)$, alors que dans le groupe lidocaine, l'IOP n'a pas augmenté ( 9.8 pour cent) significativement après l'intubation. L'IOP a diminué en bas des valcurs obtenues au temps $O$ en dedans de trois minutes après la disparition du réflexe ciliaire dans le groupe lidocaïne $(p<0.05)$. A chaque mesure (excepté au temps 0), I'IOP était significativement plus grande dans le groupe contrôle que dans le groupe lidocaïne $(p<0.05)$. La fréquence cardiaque ainsi que la tension artérielle systolique n'ont pas augmenté significativement dans aucun des groupes apres intubation. On conclut que l'administration intraveineuse de lidocä̈ne (1.5 $\mathrm{mg} \cdot \mathrm{kg}^{-1}$ ) atténue significativement l' $I O P$ en réponse à la laryngoscopie et l'intubation chez les enfants anesthésiés avec pancuronium, thiopentone et atropine. 